\title{
Fatigability and Cardiorespiratory Impairments in Parkinson's Disease: Potential Non-Motor Barriers to Activity Performance
}

\author{
Andrew E. Pechstein 1(D), Jared M. Gollie ${ }^{1,2,3, *(D)}$ and Andrew A. Guccione ${ }^{1}$ \\ 1 Department of Rehabilitation Science, George Mason University, Fairfax, VA 22030, USA; \\ apechste@masonlive.gmu.edu (A.E.P.); aguccion@gmu.edu (A.A.G.) \\ 2 Research Services, Veterans Affairs Medical Center, Washington, DC 20422, USA \\ 3 Department of Health, Human Function, and Rehabilitation Sciences, \\ The George Washington University, Washington, DC 20006, USA \\ * Correspondence: jgollie@gmu.edu
}

Received: 28 September 2020; Accepted: 29 October 2020; Published: 31 October 2020

\begin{abstract}
Parkinson's disease (PD) is the second most common neurodegenerative condition after Alzheimer's disease, affecting an estimated 160 per 100,000 people 65 years of age or older. Fatigue is a debilitating non-motor symptom frequently reported in PD, often manifesting prior to disease diagnosis, persisting over time, and negatively affecting quality of life. Fatigability, on the other hand, is distinct from fatigue and describes the magnitude or rate of change over time in the performance of activity (i.e., performance fatigability) and sensations regulating the integrity of the performer (i.e., perceived fatigability). While fatigability has been relatively understudied in PD as compared to fatigue, it has been hypothesized that the presence of elevated levels of fatigability in PD results from the interactions of homeostatic, psychological, and central factors. Evidence from exercise studies supports the premise that greater disturbances in metabolic homeostasis may underly elevated levels of fatigability in people with PD when engaging in physical activity. Cardiorespiratory impairments constraining oxygen delivery and utilization may contribute to the metabolic alterations and excessive fatigability experienced in individuals with PD. Cardiorespiratory fitness is often reduced in people with PD, likely due to the combined effects of biological aging and impairments specific to the disease. Decreases in oxygen delivery (e.g., reduced cardiac output and impaired blood pressure responses) and oxygen utilization (e.g., reduced skeletal muscle oxidative capacity) compromise skeletal muscle respiration, forcing increased reliance on anaerobic metabolism. Thus, the assessment of fatigability in people with PD may provide valuable information regarding the functional status of people with PD not obtained with measures of fatigue. Moreover, interventions that target cardiorespiratory fitness may improve fatigability, movement performance, and health outcomes in this patient population.
\end{abstract}

Keywords: oxygen consumption; perceived fatigability; endurance; walking; cardiorespiratory fitness; aerobic metabolism; autonomic nervous system

\section{Introduction}

Parkinson's disease (PD) is the second most common neurodegenerative condition after Alzheimer's disease, affecting an estimated 160 per 100,000 people 65 years of age or older [1]. With advancing age considered to be the greatest risk factor for developing PD, the projected expansion of the older adult population portends a sharp increase in the burden of PD in coming years [2]. PD is characterized by both motor and non-motor symptoms with the cause(s) including the interplay of genetic and environmental factors [3,4]. Motor dysfunction is thought to occur due to dopamine deficiency within the basal ganglia as a result of the death of dopaminergic neurons in the substantia 
nigra pars compacta [3]. However, other key dopaminergic areas of the brain may also contribute, in part, to some of the non-motor symptoms identified [4]. Furthermore, non-motor symptoms may present themselves earlier in the disease process compared to motor symptoms, which become more prominent during later stages of disease progression, and therefore may provide a more valuable prognostic indicator for the identification of individuals at risk for PD.

Fatigue is a debilitating non-motor symptom frequently reported in PD [3-6]. While fatigue has garnered much scientific and clinical interest as a symptom in PD, recent efforts have been made to distinguish the symptom of fatigue from fatigability [6]. It has been proposed that by differentiating these two constructs, unique health and functional characteristics can be ascertained [6]. Fatigability is distinct from fatigue in that it not only describes elements of human performance but also provides a framework for identifying impairments that ultimately may drive activity limitation [6]. Importantly, fatigability encompasses systems associated with perceptions of effort and sensations not associated with the symptom of fatigue, in addition to processes required for excitation-contraction coupling [6]. Greater susceptibility to fatigability may also underscore findings of increased physical inactivity in PD [7]. Currently, the concept of fatigability and its relationship to fatigue are not fully appreciated in the PD literature. This may not only hinder a more precise and robust understanding of fatigability in PD, but also may be a missed opportunity to understand a critical dimension of activity limitation in members of this patient population. Therefore, the purpose of this review is to (1) highlight key differences between the constructs of fatigue and fatigability, (2) outline evidence of elevated fatigability in PD, (3) describe fatigability during whole-body activity from a bioenergetic perspective, and (4) identify potential cardiorespiratory impairments contributing to fatigability in PD.

\section{Fatigue versus Fatigability}

\subsection{Fatigue as a Symptom}

Fatigue is a symptom defined as a subjective lack of physical and/or mental energy that is perceived by the individual to interfere with usual or desired activities commonly assessed using self-report questionnaires [8]. In PD specifically, fatigue has been characterized as a sense of exhaustion that is unexplained by drug effects or other medical or psychiatric disorders [5,6]. Fatigue is commonly reported in people with $\mathrm{PD}$, often manifesting prior to disease diagnosis, persisting over time, and negatively affecting quality of life, even when controlling for other symptoms such as depression, motor symptom severity, and sleep quality [9-16]. While the exact mechanisms causing excessive fatigue in PD are not entirely understood, proposed mechanisms include increased circulating pro-inflammatory cytokines, dysfunction in nigrostriatal and extrastriatal dopaminergic pathways, involvement of non-dopaminergic pathways, executive/prefrontal pathology, involvement of the autonomic nervous system, and low-grade systemic hypotension [6,17]. People with PD frequently identify fatigue as their most (or among their most) debilitating symptom(s) $[9,18]$. Importantly, increased fatigue has been shown to be associated with decreased physical activity in PD, a relevant factor given that exercise and a physically active lifestyle may slow or halt the progression of the disease [19-23]. However, a disassociation between objective measures of performance fatigability and the symptom fatigue have been reported in $\mathrm{PD}$, suggesting that the underlying mechanisms contributing to fatigability and fatigue likely differ [24].

\subsection{Fatigability: An Activity-Induced Construct}

Fatigability is distinct from fatigue in that it describes the magnitude or rate of change over time in the performance of activity (i.e., performance fatigability) and sensations regulating the integrity of the performer (i.e., perceived fatigability) [25]. Thus, fatigability is a direct measure of human performance that results from engaging in any physical activity. Given its link to physical activity, fatigability has been proposed as a prognostic indicator of phenotypic aging and physical resilience [26,27]. Therefore, individuals who express greater levels of fatigability, performance or perceived, are likely to be 
limited in their ability to sustain physically demanding activities. While fatigability has been relatively understudied in PD as compared to fatigue, it has been hypothesized that the presence of elevated levels of fatigability in PD results from the interactions of homeostatic, psychological, and central factors [28]. The central underlying tenant of this premise is that individuals with PD are compromised in their ability to regulate changes in energetic demands during physical activity.

\section{Evidence of Elevated Fatigability in Parkinson's Disease}

The literature indicates that both performance fatigability and perceived fatigability are often elevated in people with PD. Studies providing insight into fatigability during whole-body activities in people with PD are presented in Table 1 [29-40]. When compared to healthy controls, it is consistently reported that people with PD demonstrate reduced distance walked and lower cardiorespiratory fitness [29,30,33,35,38,39]. Multiple reports of reduced performance during less demanding exercise protocols in people with PD compared to healthy controls $[31,37,40,41]$ suggest these individuals are likely predisposed towards increased fatigability during less strenuous activities as well. Elevated perceived fatigability often occurs concomitantly with increased performance fatigability in people with PD. Ratings of perceived exertion have been reported to be higher at peak exercise in those with PD compared to healthy controls despite lower peak work rates [33,35]. Such findings indicate that individuals with PD are at greater risk for experiencing higher levels of perceived effort even when performing activities of lower intensities. Older adults without PD perform activities of daily living closer to their maximal capacities, requiring a greater level of relative effort [42]. Thus, excessive levels of fatigability in PD may be reflective of the inability to meet the bioenergetic demands required to perform a given activity due to the combination of reduced physiological capacity and impaired bioenergetic processes. 
Table 1. Studies characterizing fatigability during whole-body activities in people with Parkinson's disease (PD).

\begin{tabular}{|c|c|c|c|c|}
\hline Author(s), Year & Sample Size $(n)$, Age (Years) & Assessment & $\begin{array}{l}\text { Results: } \\
\text { Performance } \\
\text { Fatigability }\end{array}$ & $\begin{array}{l}\text { Results: } \\
\text { Perceived Fatigability }\end{array}$ \\
\hline Protas et al., 1996 [29] & $\begin{array}{c}\text { PD: } n=8,61.4 \text { (6.9) CON: } n=7 \text {, not } \\
\text { reported }\end{array}$ & $\begin{array}{l}\text { Leg cycle ergometer to volitional } \\
\text { exhaustion ( } 20 \mathrm{~W} \text { increase every } 2 \mathrm{~min}) \text {. } \\
\text { Arm cycle ergometer to volitional } \\
\text { exhaustion (10 W increase every } 2 \mathrm{~min} \text { ) }\end{array}$ & $\begin{array}{l}\text { Peak power output significantly lower in PD vs. } \\
\text { CON during leg and arm cycle ergometer tests. }\end{array}$ & n/a \\
\hline Stanley et al., 1999 [30] & $\begin{array}{l}\text { PD: } n=20, \text { not reported } \\
\text { CON: } n=23 \text {, not reported }\end{array}$ & $\begin{array}{l}\text { Leg cycle ergometer with } 20 \mathrm{~W} \text { increase } \\
\text { every } 2 \text { min until volitional exhaustion }\end{array}$ & $\begin{array}{l}\text { Peak exercise time significantly lower in PD } \\
\text { men vs. CON men. No difference in peak } \\
\text { exercise time in PD women vs. CON women. }\end{array}$ & $\mathrm{n} / \mathrm{a}$ \\
\hline Reuter et al., 1999 [31] & $\begin{aligned} \text { PD: } n & =15,63(6.17) \\
\text { CON: } n & =15,63.8(5.38)\end{aligned}$ & $\begin{array}{l}\text { Leg cycle ergometer with } 4 \text { min stages } \\
(25 \mathrm{~W}, 50 \mathrm{~W}, 75 \mathrm{~W}, 100 \mathrm{~W}, 125 \mathrm{~W}, 150 \mathrm{~W})\end{array}$ & $\begin{array}{l}\text { \% completed each stage (PD vs. CON): ( } 75 \mathrm{~W}: \\
100 \% \text { vs. } 100 \%)(100 \mathrm{~W}: 80 \% \text { vs. } 100 \%)(125 \mathrm{~W}: \\
47 \% \text { vs. } 80 \%)(150 \mathrm{~W}: 47 \% \text { vs. } 60 \%)\end{array}$ & n/a \\
\hline Canning et al., 2006 [32] & $\begin{aligned} \text { PD: } n & =16,65(6.9) \\
\text { CON: } n & =22,66.3(6.6)\end{aligned}$ & 6-Minute Walk Test & $\begin{array}{l}\text { Significantly lower total distance walked in PD } \\
\text { vs. CON. }\end{array}$ & $\begin{array}{l}\text { Perceived leg fatigue at end of test significantly higher in } \\
\text { PD vs. CON. Mean perceived shortness of breath at end of } \\
\text { test higher in PD vs. CON. }\end{array}$ \\
\hline Werner et al., 2006 [33] & $\begin{array}{l}\text { PD: } n=16, \text { not reported } \\
\text { CON: } n=11,66.1(9.4)\end{array}$ & Treadmill Modified Bruce Protocol & Mean peak work rate lower in $\mathrm{PD}$ vs. $\mathrm{CON}$. & RPE significantly higher at peak exercise in PD vs. CON. \\
\hline Christiansen et al., 2009 [34] & $\begin{array}{l}\text { PD: } n=90,64.4(10.3) \\
\text { CON: } n=44,64.6(7.3)\end{array}$ & $\begin{array}{l}\text { Treadmill walking at different speeds }(1 \\
\text { mph, } 1.5 \mathrm{mph}, 2 \mathrm{mph}, 2.5 \mathrm{mph}, 3 \mathrm{mph}, \\
3.5 \mathrm{mph})\end{array}$ & n/a & $\begin{array}{l}\text { RPE significantly higher during walking in PD vs. CON (2 } \\
\text { mph, } 2.5 \mathrm{mph}, 3 \mathrm{mph}, 3.5 \mathrm{mph}) .\end{array}$ \\
\hline DiFransisco-Donoghue et al., 2009 [35] & $\begin{array}{l}\text { PD: } n=14,67.7(6.8) \\
\text { CON: } n=15,67.1(4.4)\end{array}$ & Treadmill Modified Bruce Protocol & $\begin{array}{l}\text { Peak exercise time significantly lower in PD vs. } \\
\text { CON. }\end{array}$ & Mean RPE higher at peak exercise in PD vs. CON. \\
\hline Maggioni et al., 2012 [36] & $\begin{array}{l}\text { PD: } n=14,67.9(8.1) \\
\text { CON: } n=14,66.6(5.3)\end{array}$ & $\begin{array}{l}\text { 5-Minute Walk Test at both } \\
\text { "self-selected" and "as fast as possible" } \\
\text { speeds }\end{array}$ & $\begin{array}{l}\text { Total distance walked significantly lower in PD } \\
\text { vs. CON at "self-selected" and "as fast as } \\
\text { possible" speeds. }\end{array}$ & n/a \\
\hline Speelman et al., 2012 [37] & $\begin{array}{l}\text { PD: } n=546 \text {, not reported } \\
\text { CON: } n=29 \text {, not reported }\end{array}$ & $\begin{array}{c}\text { Astrand-Rhyming submaximal leg } \\
\text { cycle ergometer exercise test }\end{array}$ & $\begin{array}{l}\text { \% test completion (PD vs. CON): } \\
(46 \% \text { vs } 86 \%) \text {. }\end{array}$ & n/a \\
\hline Strano et al., 2016 [38] & $\begin{aligned} \text { PD: } n & =18,59.3(10.5) \\
\text { CON: } n & =18, \text { not reported }\end{aligned}$ & $\begin{array}{l}\text { Leg cycle ergometer using } \\
\text { individualized ramp protocols } \\
\text { designed to promote volitional } \\
\text { exhaustion in 6-12 min }\end{array}$ & $\begin{array}{l}\text { Peak power output significantly lower in PD } \\
\text { vs. CON. }\end{array}$ & n/a \\
\hline Kanegusuku et al., 2016 [39] & $\begin{array}{l}\text { PD: } n=48,66(8) \\
\text { CON: } n=20,64(9)\end{array}$ & $\begin{array}{l}\text { Leg cycle ergometer using } \\
\text { individualized ramp protocols } \\
\text { designed to promote volitional } \\
\text { exhaustion in } 8-12 \mathrm{~min}\end{array}$ & $\begin{array}{l}\text { Workload at RCP significantly lower in PD vs. } \\
\text { CON. Mean workload at AT lower in PD vs. } \\
\text { CON. }\end{array}$ & n/a \\
\hline Roberson et al., 2019 [40] & $\begin{array}{l}\text { PD: } n=14,68(12) \\
\text { CON: } n=16,66(7)\end{array}$ & $\begin{array}{l}\text { Leg cycle ergometer using } 3 \text { min stages } \\
(35 \mathrm{~W}, 55 \mathrm{~W}, 75 \mathrm{~W}, 95 \mathrm{~W}, 115 \mathrm{~W})\end{array}$ & $\begin{array}{l}\text { \% completed each stage (PD vs. CON): } \\
\text { (stage 1: } 100 \% \text { vs. } 100 \% \text { ) (stage 2: } 93 \% \text { vs. } \\
100 \% \text { ) (stage 3: } 71 \% \text { vs. } 81 \% \text { ) (stage 4: } 43 \% \text { vs. } \\
\text { 75\%) (stage 5: } 0 \% \text { vs. } 38 \% \text { ). }\end{array}$ & Mean RPE higher at peak exercise in PD vs. CON. \\
\hline
\end{tabular}




\section{Fatigability from a Bioenergetic Perspective}

The cardiorespiratory system, in conjunction with skeletal muscle bioenergetic systems, supports the energy synthesis required to maintain muscle contraction. Cross-sectional and interventional studies have provided evidence of a strong association between cardiorespiratory fitness and fatigability in individuals across a wide range of ages and patient populations [43-51]. Biological aging results in declines in cardiorespiratory fitness due to reductions in cardiac output and arteriovenous oxygen difference beginning around the third decade with accelerated decreases occurring around the sixth decade and beyond [45]. Insufficient oxygen delivery is considered the primary factor contributing to activity termination during maximal aerobic activity [52,53]. In contrast, activity termination during prolonged submaximal activity results from factors related to oxygen utilization and/or perceived effort associated with activity performance [52-54]. During dynamic muscular activity, fatigability is shown to be strongly associated with increased metabolite accumulation in older adults due to a preferential reliance on anaerobic bioenergetic systems [55]. The rise in metabolite concentrations is implicated as an underlying mechanism contributing to impaired skeletal muscle cross-bridge formation and heightened sensations of activity-induced discomfort [56-61].

The signs and symptoms of PD are typically seen as emerging from a primarily "neurological" condition, however, reduced cardiorespiratory fitness may be an underappreciated contributor to elevated fatigability in this population. While studies investigating peak oxygen consumption $\left(\mathrm{VO}_{2}\right)$ between people with PD and controls are not conclusive [29,30], most findings point to lower peak $\mathrm{VO}_{2}$ in people with $\mathrm{PD}$. Moreover, the literature widely reports reductions in various submaximal indices of aerobic function and substantial limitations in exercise performance in the PD population [29-31,33,35,37-41,62]. Several factors are likely to contribute to low cardiorespiratory fitness in PD including cardiorespiratory alterations due to aging, physical inactivity, and cardiorespiratory impairments specific to the pathophysiology of PD. For example, adults 65 years of age and older comprise the largest portion of the PD population and are thus likely to be impacted by age-related declines in cardiorespiratory fitness [63-66]. High levels of physical inactivity have been reported in people with PD which were found to be associated with greater disease severity, gait impairment, and greater disability in daily living [7]. In addition to these factors, individuals with PD often require greater energetic costs during activities such as walking [67]. The increased energetic cost combined with lower cardiorespiratory fitness places greater strain on the cardiorespiratory and skeletal muscle bioenergetic systems to meet the energetic requirements for activity. The decreased capacity to support aerobic energy synthesis promoting increased anaerobic metabolic contributions may explain the potential elevations in performance fatigability and perceived fatigability in individuals with PD [28]. The subsequent sections of this review will detail how cardiorespiratory impairments, especially alterations in oxygen delivery and oxygen utilization, are likely to influence fatigability in this patient population.

\section{Cardiorespiratory Impairments Contributing to Fatigability in Parkinson's Disease}

To date, factors contributing to performance fatigability and perceived fatigability in PD during various activities have not been fully elucidated. Given that age is a primary risk factor for PD, age-related factors limiting oxygen delivery and utilization during physical activity present themselves as likely candidates contributing to elevations in fatigability in PD. These factors include reductions in cardiac output, redistribution of blood flow away from oxidative fibers, impaired endothelium-mediated vasodilation, and potential reductions in muscle mitochondrial density and function [66,68-74]. As such, insufficient oxygen delivery and utilization may constrain skeletal muscle respiration in older adults, placing greater reliance on anaerobic bioenergetic systems for energy synthesis. Additionally, insufficient blood flow in older adults may also impair metabolite removal which further promotes metabolite accumulation, thus exacerbating deficits in muscle performance and increasing sensations associated with effort and exertion $[60,61,75,76]$. Beyond potential age-related constraints, several observations support the notion that factors specific to the pathophysiology of PD further 
compound age-related alterations in oxygen delivery and utilization. Figure 1 depicts the potential relationships between PD, fatigability, and cardiorespiratory impairments.

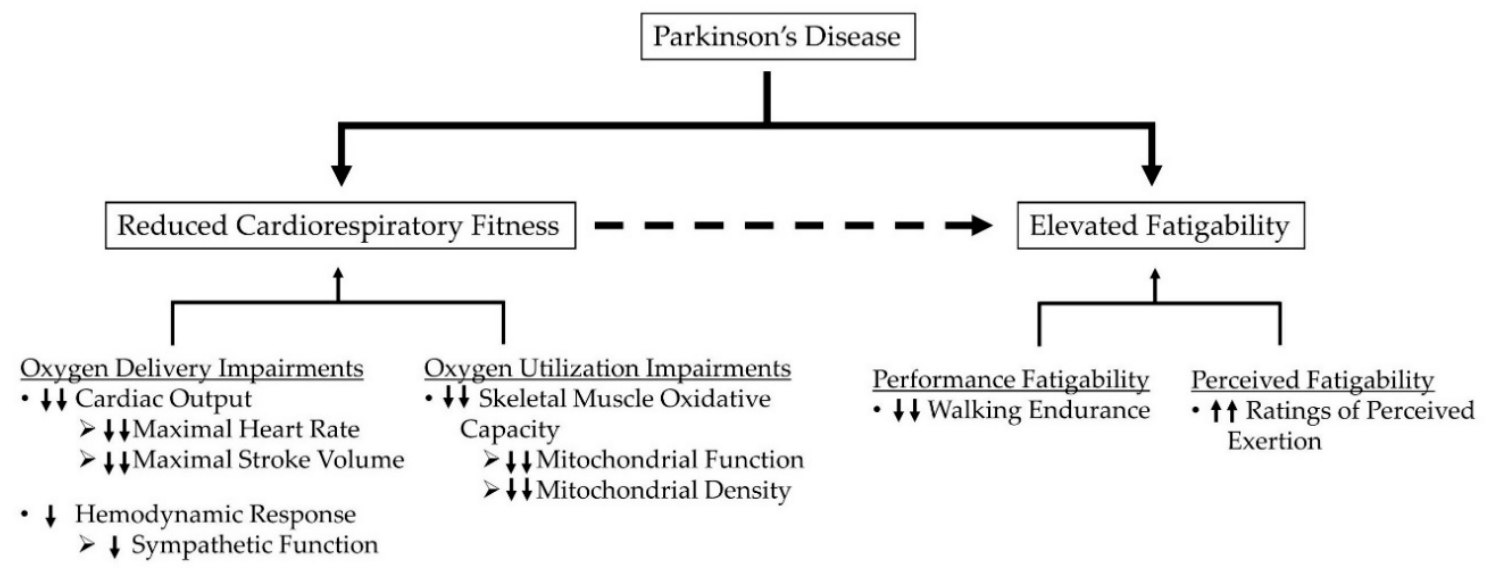

Figure 1. Hypothesized schematic representation of potential relationships between PD, fatigability, and cardiorespiratory impairments. Single arrows represent the impairments independently related to PD, while double arrows represent impairments related to the combination of PD and aging.

\subsection{Oxygen Delivery}

Autopsy investigations $[77,78]$ and studies employing functional imaging or catheterization techniques revealed sympathetic denervation of cardiac muscle in people with PD [77,79-96]. The alteration in sympathetic activity is found to occur early in the disease process [97], sometimes even preceding the onset of clinically apparent motor symptoms [98,99], and increases in severity with disease progression [100]. Individuals with PD often fail to reach their age-predicted maximal heart rate $(\mathrm{HR})$ at peak exercise $[33,40,101]$. Increased fatigability is often reported alongside decreased peak $\mathrm{VO}_{2}$ and decreased peak $\mathrm{HR}$ in people with PD compared to healthy controls [35,38,39,62]. In addition to aberrant HR responses, cardiac contractility may also be impaired in people with PD, the severity of which likely corresponds to the degree of sympathetic denervation of the heart [41].

Degeneration of key cardiovascular control centers in the brain [100,102-108] and sympathetic denervation in the thyroid and renal cortex have also been reported in people with PD $[81,109,110]$. While the collective influence of these pathological alterations on hemodynamics and exercise performance is not completely described, reduced systolic blood (BP) pressure responses to exercise are commonly observed in people with PD [31,33,35,39,111]. For example, it was recently reported that, in comparison to healthy controls, systemic vascular resistance dropped more precipitously upon initiation of exercise in people with PD [40], suggesting that sympathetic control over vascular conductance may be reduced in members of this patient population. Additionally, blunted increases in systolic $\mathrm{BP}$ have been associated with increased fatigability [33] and reduced $\mathrm{VO}_{2}$ in people with PD compared to healthy controls $[35,39]$. Factors that are likely relevant to loss of control over arterial pressure during activity in people with PD include baroreflex failure [109], impaired metaboreflex vasoconstrictor responses [112-114], decreased muscle sympathetic nerve activity $[115,116]$, reduced norepinephrine release $[35,109,117,118]$, or a confluence of these factors in combination with reduced cardiac performance. Failure to adequately increase systolic BP during exercise, which can occur secondary to either reduced cardiac output or loss of sympathetic control over vascular conductance, may compromise perfusion of active muscle $[119,120]$. Inadequate muscle perfusion negatively impacts aerobic metabolism [119,121], reduces skeletal muscle contractile performance [122-124], and contributes to elevated sensations of activity-induced discomfort. Thus, these data posit limitations in maximal HR, reductions in cardiac contractility, and deleterious alterations in sympathetic control over vascular conductance as factors that may constrain oxygen delivery to working muscles and contribute to increased fatigability in people with PD. 


\subsection{Oxygen Utilization}

Cardiorespiratory fitness and fatigability are also affected by the functional state of skeletal muscle and factors that influence oxidative phosphorylation [73]. Although one of the earliest studies of skeletal muscle in PD provided anatomical evidence to suggest that mitochondria were negatively impacted in this patient population [125], data from subsequent studies investigating the possibility of muscle mitochondrial impairment in PD were inconclusive [126-136], perhaps due to methodological differences [137]. More recently, studies have corroborated findings of impaired respiratory capacity in mitochondria [137-139]. Although a critique of the evidence of mitochondrial impairments in PD is outside the scope of this review, future research should consider whether compromised oxygen utilization contributes to fatigability in this patient population, especially when engaging in activities reliant on oxidative energy synthesis such as prolonged walking. Structural and functional alterations in the intrinsic dynamics of oxidative phosphorylation may impair aerobic energy synthesis and elevate fatigability [73]. However, the degree to which fatigability and reduced cardiorespiratory fitness in PD are attributable to deficits in oxygen utilization is not well established as these relationships have not been directly assessed in this patient population.

\section{Clinical Considerations}

Increased fatigability in PD may be considered a sign of low exercise capacity, impending frailty, and negative health outcomes, and is therefore important to monitor clinically [26,27]. The more rapid deterioration of performance and greater sense of exertion during activity may discourage individuals with PD from initiating positive behavior changes towards a more physically active lifestyle [140]. Aerobic exercise training has garnered increased attention in PD as a complimentary treatment to pharmacologic options due to its potential positive impact on motor symptoms, cognition, brain health, and disease progression [20,141,142]. Additionally, as noted by a recent systematic review, aerobic training appears to be a viable strategy for improving cardiorespiratory fitness as measured by peak $\mathrm{VO}_{2}$, performance fatigability as measured by walking distance, peak work rate, or exercise test duration, and perceived fatigability as measured by ratings of perceived exertion during walking tests [143]. However, results are not uniform and large variation between studies in terms of frequency and intensity of training, program duration, and testing mode (i.e., treadmill vs. bicycle) makes it difficult to determine which elements of the overall program design are most essential for improving cardiorespiratory fitness and fatigability. Moreover, exposure to sufficient exercise intensity and volume may be difficult in people with PD who experience excessive fatigability during physical activity and exercise. Training parameters, therefore, such as intensity, volume, and duration, should be carefully manipulated in an individualized fashion to gradually introduce and increase workloads and maximize tolerability. Patients should always consult with a physician prior to engaging in exercise and may benefit from working with a multidisciplinary team of medical and rehabilitation professionals to improve safety and maximize benefits of training. Future studies should aim to establish the validity and reliability of fatigability measures in the PD population and to determine the effectiveness of exercise interventions targeting cardiorespiratory fitness and fatigability.

\section{Summary}

Fatigue and fatigability, when viewed as distinct constructs and assessed separately, provide unique health and functional information. This article extends current understandings of fatigability in PD by positing disturbances in metabolic homeostasis resulting from cardiorespiratory impairments as a potential explanation for elevated fatigability in this population. The exact contributions of biological aging and the pathophysiological consequences of PD to diminished cardiorespiratory fitness in PD are not completely known, however, this article illuminates several plausible factors likely to impair oxygen delivery and oxygen utilization during physical activity. Future research is needed to 
determine which fatigability assessments are most appropriate for individuals with PD as well as the responsiveness of fatigability measures to therapeutic interventions.

Author Contributions: Conceptualization, A.E.P., J.M.G., A.A.G.; writing-original draft preparation, A.E.P., J.M.G., A.A.G.; writing—review and editing, A.E.P., J.M.G., A.A.G.; visualization, A.E.P., J.M.G., A.A.G. All authors have read and agreed to the published version of the manuscript.

Funding: This research received no external funding.

Conflicts of Interest: The authors declare no conflict of interest.

\section{References}

1. Ascherio, A.; Schwarzschild, M.A. The epidemiology of Parkinson's disease: Risk factors and prevention. Lancet Neurol. 2016, 15, 1257-1272. [CrossRef]

2. Kowal, S.L.; Dall, T.M.; Chakrabarti, R.; Storm, M.V.; Jain, A. The current and projected economic burden of Parkinson's disease in the United States: Economic Burden of PD in the US. Mov. Disord. 2013, 28, 311-318. [CrossRef]

3. Kalia, L.V.; Lang, A.E. Parkinson's disease. Lancet 2015, 386, 896-912. [CrossRef]

4. Chaudhuri, K.R.; Schapira, A.H. Non-motor symptoms of Parkinson's disease: Dopaminergic pathophysiology and treatment. Lancet Neurol. 2009, 8, 464-474. [CrossRef]

5. Friedman, J.H.; Beck, J.C.; Chou, K.L.; Clark, G.; Fagundes, C.P.; Goetz, C.G.; Herlofson, K.; Kluger, B.; Krupp, L.B.; Lang, A.E.; et al. Fatigue in Parkinson's disease: Report from a mutidisciplinary symposium. NPJ Parkinson's Dis. 2016, 2, 1-6. [CrossRef] [PubMed]

6. Kluger, B.M.; Herlofson, K.; Chou, K.L.; Lou, J.-S.; Goetz, C.G.; Lang, A.E.; Weintraub, D.; Friedman, J. Parkinson's disease-related fatigue: A case definition and recommendations for clinical research. Mov. Disord. 2016, 31, 625-631. [CrossRef]

7. Nimwegen, M.; Speelman, A.D.; Hofman-van Rossum, E.J.M.; Overeem, S.; Deeg, D.J.H.; Borm, G.F.; Horst, M.H.L.; Bloem, B.R.; Munneke, M. Physical inactivity in Parkinson's disease. J. Neurol. 2011, 258, 2214-2221. [CrossRef] [PubMed]

8. Eldadah, B.A. Fatigue and fatigability in older adults. PMER 2010, 2, 406-413.

9. Friedman, J.H.; Brown, R.G.; Comella, C.; Garber, C.E.; Krupp, L.B.; Lou, J.-S.; Marsh, L.; Nail, L.; Shulman, L.; Taylor, C.B. Fatigue in Parkinson's disease: A review. Mov. Disord. 2007, 22, 297-308. [CrossRef]

10. Schrag, A.; Horsfall, L.; Walters, K.; Noyce, A.; Petersen, I. Prediagnostic presentations of Parkinson's disease in primary care: A case-control study. Lancet Neurol. 2015, 14, 57-64. [CrossRef]

11. Alves, G.; Wentzel-Larsen, T.; Larsen, J.P. Is fatigue an independent and persistent symptom in patients with Parkinson disease? Neurology 2004, 63, 1908-1911. [CrossRef] [PubMed]

12. Dogan, V.B.; Koksal, A.; Dirican, A.; Baybas, S.; Dirican, A.; Dogan, G.B. Independent effect of fatigue on health-related quality of life in patients with idiopathic Parkinson's disease. Neurol. Sci. 2015, 36, 2221-2226. [CrossRef] [PubMed]

13. Gallagher, D.A.; Lees, A.J.; Schrag, A. What are the most important nonmotor symptoms in patients with Parkinson's disease and are we missing them? Mov. Disord. 2010, 25, 2493-2500. [CrossRef]

14. Gofton, T.E.; Kumar, H.; Roberts-South, A.; Speechley, M.; Jog, M.S. Validity, reliability, and insights from applying the McGill Quality of Life Questionnaire to People Living with Parkinson's Disease (MQoL-PD). J. Palliat. Care 2015, 31, 213-220. [CrossRef]

15. Prakash, K.M.; Nadkarni, N.V.; Lye, W.-K.; Yong, M.-H.; Tan, E.-K. The impact of non-motor symptoms on the quality of life of Parkinson's disease patients: A longitudinal study. Eur. J. Neurol. 2016, 23, 854-860. [CrossRef]

16. Kluger, B.M. Chapter twenty-four-fatigue in Parkinson's disease. In International Review of Neurobiology; Nonmotor Parkinson's: The Hidden Face; Chaudhuri, K.R., Titova, N., Eds.; Academic Press: Cambridge, MA, USA, 2017; Volume 133, pp. 743-768.

17. Kotagal, V.; Szpara, A.; Albin, R.L.; Bohnen, N.I. Fatigue in parkinson's disease associates with lower ambulatory diastolic blood pressure. J. Parkinsons. Dis. 2019, 9, 575-581. [CrossRef] 
18. Pont-Sunyer, C.; Hotter, A.; Gaig, C.; Seppi, K.; Compta, Y.; Katzenschlager, R.; Mas, N.; Hofeneder, D.; Brücke, T.; Bayés, A.; et al. The onset of nonmotor symptoms in Parkinson's disease (the ONSET PD study). Mov. Disord. 2015, 30, 229-237.

19. Loprinzi, P.D.; Herod, S.M.; Cardinal, B.J.; Noakes, T.D. Physical activity and the brain: A review of this dynamic, bi-directional relationship. Brain Res. 2013, 1539, 95-104. [CrossRef]

20. Ahlskog, J.E. Aerobic exercise: Evidence for a direct brain effect to slow parkinson disease progression. Mayo Clin. Proc. 2018, 93, 360-372. [CrossRef]

21. Ahlskog, J.E. Does vigorous exercise have a neuroprotective effect in Parkinson disease? Neurology 2011, 77, 288-294. [CrossRef] [PubMed]

22. Petzinger, G.M.; Fisher, B.E.; McEwen, S.; Beeler, J.A.; Walsh, J.P.; Jakowec, M.W. Exercise-enhanced neuroplasticity targeting motor and cognitive circuitry in Parkinson's disease. Lancet Neurol. 2013, 12, 716-726. [CrossRef]

23. Garber, C.E.; Friedman, J.H. Effects of fatigue on physical activity and function in patients with Parkinson's disease. Neurology 2003, 60, 1119-1124. [CrossRef] [PubMed]

24. Lou, J.-S.; Kearns, G.; Oken, B.; Sexton, G.; Nutt, J. Exacerbated physical fatigue and mental fatigue in Parkinson's disease. Mov. Disord. 2001, 16, 190-196. [CrossRef] [PubMed]

25. Enoka, R.M.; Duchateau, J. Translating fatigue to human performance. Med. Sci. Sports Exerc. 2016, 48, 2228-2238. [CrossRef]

26. Whitson, H.E.; Duan-Porter, W.; Schmader, K.E.; Morey, M.C.; Cohen, H.J.; Colón-Emeric, C.S. Physical resilience in older adults: Systematic review and development of an emerging construct. J. Gerontol. Series $A$ Biol. Sci. Med Sci. 2016, 71, 489-495. [CrossRef]

27. Schrack, J.A.; Simonsick, E.M.; Glynn, N.W. Fatigability: A Prognostic indicator of phenotypic aging. J. Gerontol. A Biol. Sci. Med. Sci. 2020, 75, e63-e66. [CrossRef]

28. Kluger, B.M.; Krupp, L.B.; Enoka, R.M. Fatigue and fatigability in neurologic illnesses. Neurology 2013, 80, 409-416. [CrossRef]

29. Protas, E.J.; Stanley, R.K.; Jankovic, J.; MacNeill, B. Cardiovascular and metabolic responses to upper- and lower-extremity exercise in men with idiopathic Parkinson's disease. Phys. Ther. 1996, 76, 34-40. [CrossRef]

30. Stanley, R.K.; Protas, E.J.; Jankovic, J. Exercise performance in those having Parkinson's disease and healthy normals. Med. Sci. Sports Exerc. 1999, 31,761-766. [CrossRef]

31. Reuter, I.; Engelhardt, M.; Freiwaldt, J.; Baas, H. Exercise test in Parkinson's disease. Clin. Auton. Res. 1999, 9, 129-134. [CrossRef]

32. Canning, C.G.; Ada, L.; Johnson, J.J.; McWhirter, S. Walking capacity in mild to moderate Parkinson's disease. Arch. Phys. Med. Rehabil. 2006, 87, 371-375. [CrossRef] [PubMed]

33. Werner, W.G.; DiFrancisco-Donoghue, J.; Lamberg, E.M. Cardiovascular response to treadmill testing in parkinson disease. J. Neurol. Phys. Ther. 2006, 30, 68. [CrossRef] [PubMed]

34. Christiansen, C.L.; Schenkman, M.L.; McFann, K.; Wolfe, P.; Kohrt, W.M. Walking economy in people with Parkinson's disease. Mov. Disord. 2009, 24, 1481-1487. [CrossRef]

35. DiFrancisco-Donoghue, J.; Elokda, A.; Lamberg, E.M.; Bono, N.; Werner, W.G. Norepinephrine and cardiovascular responses to maximal exercise in Parkinson's disease on and off medication. Mov. Disord. 2009, 24, 1773-1778. [CrossRef]

36. Maggioni, M.A.; Veicsteinas, A.; Rampichini, S.; Cè, E.; Nemni, R.; Riboldazzi, G.; Merati, G. Energy cost of spontaneous walking in Parkinson's disease patients. Neurol. Sci. 2012, 33, 779-784. [CrossRef]

37. Speelman, A.D.; Groothuis, J.T.; van Nimwegen, M.; van der Scheer, E.S.; Borm, G.F.; Bloem, B.R.; Hopman, M.T.E.; Munneke, M. Cardiovascular responses during a submaximal exercise test in patients with Parkinson's disease. J. Parkinsons. Dis. 2012, 2, 241-247. [CrossRef] [PubMed]

38. Strano, S.; Fanciulli, A.; Rizzo, M.; Marinelli, P.; Palange, P.; Tiple, D.; Vincentis, G.D.; Calcagnini, G.; Censi, F.; $\mathrm{Meco}, \mathrm{G}$; ; et al. Cardiovascular dysfunction in untreated Parkinson's disease: A multi-modality assessment. J. Neurol. Sci. 2016, 370, 251-255. [CrossRef] [PubMed]

39. Kanegusuku, H.; Silva-Batista, C.; Peçanha, T.; Nieuwboer, A.; Silva, N.D.; Costa, L.A.; de Mello, M.T.; Piemonte, M.E.; Ugrinowitsch, C.; Forjaz, C.L. Blunted maximal and submaximal responses to cardiopulmonary exercise tests in patients with parkinson disease. Arch. Phys. Med. Rehabil. 2016, 97, 720-725. [CrossRef] 
40. Roberson, K.B.; Signorile, J.F.; Singer, C.; Jacobs, K.A.; Eltoukhy, M.; Ruta, N.; Mazzei, N.; Buskard, A.N.L. Hemodynamic responses to an exercise stress test in Parkinson's disease patients without orthostatic hypotension. Appl. Physiol. Nutr. Metab. 2019, 44, 751-758. [CrossRef]

41. Nakamura, T.; Hirayama, M.; Yamashita, F.; Uchida, K.; Hama, T.; Watanabe, H.; Sobue, G. Lowered cardiac sympathetic nerve performance in response to exercise in Parkinson's disease. Mov. Disord. 2010, 25, 1183-1189. [CrossRef]

42. Hortobágyi, T.; Mizelle, C.; Beam, S.; DeVita, P. Old adults perform activities of daily living near their maximal capabilities. J. Gerontol. A Biol. Sci. Med. Sci. 2003, 58, M453-M460. [CrossRef] [PubMed]

43. Santanasto, A.J.; Glynn, N.W.; Jubrias, S.A.; Conley, K.E.; Boudreau, R.M.; Amati, F.; Mackey, D.C.; Simonsick, E.M.; Strotmeyer, E.S.; Coen, P.M.; et al. Skeletal muscle mitochondrial function and fatigability in older adults. J. Gerontol. A Biol. Sci. Med. Sci. 2015, 70, 1379-1385. [CrossRef]

44. Coen, P.M.; Jubrias, S.A.; Distefano, G.; Amati, F.; Mackey, D.C.; Glynn, N.W.; Manini, T.M.; Wohlgemuth, S.E.; Leeuwenburgh, C.; Cummings, S.R.; et al. Skeletal muscle mitochondrial energetics are associated with maximal aerobic capacity and walking speed in older adults. J. Gerontol. A Biol. Sci. Med. Sci. 2013, 68, 447-455. [CrossRef]

45. Tanaka, H.; Seals, D.R. Endurance exercise performance in Masters athletes: Age-associated changes and underlying physiological mechanisms. J. Physiol. 2008, 586, 55-63. [CrossRef] [PubMed]

46. Keyser, R.E.; Christensen, E.J.; Chin, L.M.K.; Woolstenhulme, J.G.; Drinkard, B.; Quinn, A.; Connors, G.; Weir, N.A.; Nathan, S.D.; Chan, L.E. Changes in fatigability following intense aerobic exercise training in patients with interstitial lung disease. Respir. Med. 2015, 109, 517-525. [CrossRef] [PubMed]

47. Chin, L.M.K.; Chan, L.; Drinkard, B.; Keyser, R.E. Oxygen uptake on-kinetics before and after aerobic exercise training in individuals with traumatic brain injury. Disabil. Rehabil. 2019, 41, 2949-2957. [CrossRef] [PubMed]

48. Gollie, J.M.; Herrick, J.E.; Keyser, R.E.; Chin, L.M.K.; Collins, J.P.; Shields, R.K.; Panza, G.S.; Guccione, A.A. Fatigability, oxygen uptake kinetics and muscle deoxygenation in incomplete spinal cord injury during treadmill walking. Eur. J. Appl. Physiol. 2017, 117, 1989-2000. [CrossRef]

49. Lepers, R.; Stapley, P.J. Master athletes are extending the limits of human endurance. Front. Physiol. 2016, 7, 613. [CrossRef]

50. Kelly, J.O.; Kilbreath, S.L.; Davis, G.M.; Zeman, B.; Raymond, J. Cardiorespiratory fitness and walking ability in subacute stroke patients. Arch. Phys. Med. Rehabil. 2003, 84, 1780-1785. [CrossRef]

51. Keyser, R.E.; Woolstenhulme, J.G.; Chin, L.M.K.; Nathan, S.D.; Weir, N.A.; Connors, G.; Drinkard, B.; Lamberti, J.; Chan, L. Cardiorespiratory function before and after aerobic exercise training in patients with interstitial lung disease. J. Cardiopulm. Rehabil. Prev. 2015, 35, 47-55. [CrossRef]

52. Bassett, D.R.; Howley, E.T. Limiting factors for maximum oxygen uptake and determinants of endurance performance. Med. Sci. Sports Exerc. 2000, 32, 70-84. [CrossRef] [PubMed]

53. Poole, D.C.; Ferreira, L.F.; Behnke, B.J.; Barstow, T.J.; Jones, A.M. The final frontier: Oxygen flux into muscle at exercise onset. Exerc. Sport Sci. Rev. 2007, 35, 166-173. [CrossRef] [PubMed]

54. Souron, R.; Voirin, A.; Kennouche, D.; Espeit, L.; Millet, G.Y.; Rupp, T.; Lapole, T. Task failure during sustained low-intensity contraction is not associated with a critical amount of central fatigue. Scand J. Med. Sci. Sports 2020. [CrossRef] [PubMed]

55. Sundberg, C.W.; Fitts, R.H. Bioenergetic basis of skeletal muscle fatigue. Curr. Opin. Physiol. 2019, 10, $118-127$. [CrossRef]

56. Keyser, R.E. Peripheral Fatigue: High-Energy Phosphates and Hydrogen Ions. PMER 2010, 2, $347-358$.

57. Fitts, R.H. Cellular, molecular, and metabolic basis of muscle fatigue. In Comprehensive Physiology; Terjung, R., Ed.; John Wiley \& Sons, Inc.: Hoboken, NJ, USA, 2011; ISBN 978-0-470-65071-4.

58. Allen, D.G.; Lamb, G.D.; Westerblad, H. Skeletal muscle fatigue: Cellular mechanisms. Physiol. Rev. 2008, 88, 287-332. [CrossRef]

59. Gandevia, S.C. Spinal and supraspinal factors in human muscle fatigue. Physiol. Rev. 2001, 81, 1725-1789. [CrossRef]

60. Taylor, J.L.; Amann, M.; Duchateau, J.; Meeusen, R.; Rice, C.L. Neural contributions to muscle fatigue: From the brain to the muscle and back again. Med. Sci. Sports Exerc. 2016, 48, 2294-2306. [CrossRef]

61. Amann, M. Significance of group III and IV muscle afferents for the endurance exercising human. Clin. Exp. Pharmacol. Physiol. 2012, 39, 831-835. [CrossRef] 
62. Mavrommati, F.; Collett, J.; Franssen, M.; Meaney, A.; Sexton, C.; Dennis-West, A.; Betts, J.F.; Izadi, H.; Bogdanovic, M.; Tims, M.; et al. Exercise response in Parkinson's disease: Insights from a cross-sectional comparison with sedentary controls and a per-protocol analysis of a randomised controlled trial. BMJ Open 2017, 7, e017194. [CrossRef]

63. Driver, J.A.; Logroscino, G.; Gaziano, J.M.; Kurth, T. Incidence and remaining lifetime risk of Parkinson disease in advanced age. Neurology 2009, 72, 432-438. [CrossRef] [PubMed]

64. Van Den Eeden, S.K.; Tanner, C.M.; Bernstein, A.L.; Fross, R.D.; Leimpeter, A.; Bloch, D.A.; Nelson, L.M. Incidence of Parkinson's Disease: Variation by Age, Gender, and Race/Ethnicity. Am. J. Epidemiol. 2003, 157, 1015-1022. [CrossRef] [PubMed]

65. Kaminsky, L.A.; Arena, R.; Myers, J. Reference standards for cardiorespiratory fitness measured with cardiopulmonary exercise testing: Data from the fitness registry and the importance of exercise national database. Mayo Clin. Proc. 2015, 90, 1515-1523. [CrossRef] [PubMed]

66. Betik, A.C.; Hepple, R.T. Determinants of VO2 max decline with aging: An integrated perspective. Appl. Physiol. Nutr. Metab. 2008, 33, 130-140. [CrossRef]

67. Katzel, L.I.; Ivey, F.M.; Sorkin, J.D.; Macko, R.F.; Smith, B.; Shulman, L.M. Impaired Economy of Gait and Decreased Six-Minute Walk Distance in Parkinson's Disease. Available online: https://www.hindawi.com/ journals/pd/2012/241754/ (accessed on 12 June 2019).

68. Poole, D.C.; Musch, T.I. Mechanistic insights into how advanced age moves the site of (.)VO2 kinetics limitation upstream. J. Appl. Physiol. 2010, 108, 5-6. [CrossRef] [PubMed]

69. Behnke, B.J.; Delp, M.D. Aging blunts the dynamics of vasodilation in isolated skeletal muscle resistance vessels. J. Appl. Physiol. 2010, 108, 14-20. [CrossRef]

70. Behnke, B.J.; Delp, M.D.; Dougherty, P.J.; Musch, T.I.; Poole, D.C. Effects of aging on microvascular oxygen pressures in rat skeletal muscle. Respir. Physiol. Neurobiol. 2005, 146, 259-268. [CrossRef]

71. Musch, T.I.; Eklund, K.E.; Hageman, K.S.; Poole, D.C. Altered regional blood flow responses to submaximal exercise in older rats. J. Appl. Physiol. 2004, 96, 81-88. [CrossRef]

72. Koga, S.; Rossiter, H.B.; Heinonen, I.; Musch, T.I.; Poole, D.C. Dynamic heterogeneity of exercising muscle blood flow and $\mathrm{O}_{2}$ utilization. Med. Sci. Sports Exerc. 2014, 46, 860-876. [CrossRef]

73. Conley, K.E. Mitochondria to motion: Optimizing oxidative phosphorylation to improve exercise performance. J. Exp. Biol. 2016, 219, 243-249. [CrossRef]

74. Conley, K.E.; Amara, C.E.; Jubrias, S.A.; Marcinek, D.J. Mitochondrial function, fibre types and ageing: New insights from human muscle in vivo. Exp. Physiol. 2007, 92, 333-339. [CrossRef]

75. Robertson, R.J.; Noble, B.J. Perception of physical exertion: Methods, mediators, and applications. Exerc. Sport Sci. Rev. 1997, 25, 407-452. [CrossRef]

76. Brooks, G.A.; Fahey, T.D.; Baldwin, K.M. Exercise Physiology: Human Bioenergetics and Its Applications, 4th ed.; McGraw-Hill: New York, NY, USA, 2006.

77. Orimo, S.; Ozawa, E.; Oka, T.; Nakade, S.; Tsuchiya, K.; Yoshimoto, M.; Wakabayashi, K.; Takahashi, H. Different histopathology accounting for a decrease in myocardial MIBG uptake in PD and MSA. Neurology 2001, 57, 1140-1141. [CrossRef]

78. Orimo, S.; Oka, T.; Miura, H.; Tsuchiya, K.; Mori, F.; Wakabayashi, K.; Nagao, T.; Yokochi, M. Sympathetic cardiac denervation in Parkinson's disease and pure autonomic failure but not in multiple system atrophy. J. Neurol. Neurosurg. Psychiatry 2002, 73, 776-777. [CrossRef]

79. Goldstein, D.S.; Holmes, C.; Li, S.T.; Bruce, S.; Metman, L.V.; Cannon, R.O. Cardiac sympathetic denervation in Parkinson disease. Ann. Intern. Med. 2000, 133, 338-347. [CrossRef] [PubMed]

80. Goldstein, D.S.; Holmes, C.; Cannon, R.O.; Eisenhofer, G.; Kopin, I.J. Sympathetic cardioneuropathy in dysautonomias. N. Engl. J. Med. 1997, 336, 696-702. [CrossRef]

81. Goldstein, D.S.; Holmes, C.S.; Dendi, R.; Bruce, S.R.; Li, S.-T. Orthostatic hypotension from sympathetic denervation in Parkinson's disease. Neurology 2002, 58, 1247-1255. [CrossRef] [PubMed]

82. Li, S.-T.; Dendi, R.; Holmes, C.; Goldstein, D.S. Progressive loss of cardiac sympathetic innervation in Parkinson's disease. Ann. Neurol. 2002, 52, 220-223. [CrossRef]

83. Akincioglu, C.; Unlu, M.; Tunc, T. Cardiac innervation and clinical correlates in idiopathic Parkinson's disease. Nucl. Med. Commun. 2003, 24, 267-271. [CrossRef] [PubMed] 
84. Taki, J.; Nakajima, K.; Hwang, E.H.; Matsunari, I.; Komai, K.; Yoshita, M.; Sakajiri, K.; Tonami, N. Peripheral sympathetic dysfunction in patients with Parkinson's disease without autonomic failure is heart selective and disease specific. Eur. J. Nucl. Med. 2000, 27, 566-573. [CrossRef] [PubMed]

85. Yoshita, M.; Hayashi, M.; Hirai, S. Iodine 123-labeled meta-iodobenzylguanidine myocardial scintigraphy in the cases of idiopathic Parkinson's disease, multiple system atrophy, and progressive supranuclear palsy. Rinsho Shinkeigaku 1997, 37, 476-482.

86. Orimo, S.; Ozawa, E.; Nakade, S.; Sugimoto, T.; Mizusawa, H. 123I-metaiodobenzylguanidine myocardial scintigraphy in Parkinson's disease. J. Neurol. Neurosurg. Psychiatry 1999, 67, 189-194. [CrossRef] [PubMed]

87. Takatsu, H.; Nishida, H.; Matsuo, H.; Watanabe, S.; Nagashima, K.; Wada, H.; Noda, T.; Nishigaki, K.; Fujiwara, H. Cardiac sympathetic denervation from the early stage of Parkinson's disease: Clinical and experimental studies with radiolabeled MIBG. J. Nucl. Med. 2000, 41, 71-77. [PubMed]

88. Senard, J.M.; Brefel-Courbon, C.; Rascol, O.; Montastruc, J.L. Orthostatic hypotension in patients with Parkinson's disease: Pathophysiology and management. Drugs Aging 2001, 18, 495-505. [CrossRef] [PubMed]

89. Braune, S.; Reinhardt, M.; Bathmann, J.; Krause, T.; Lehmann, M.; Lücking, C.H. Impaired cardiac uptake of meta-[123I]iodobenzylguanidine in Parkinson's disease with autonomic failure. Acta Neurol. Scand. 1998, 97, 307-314. [CrossRef] [PubMed]

90. Braune, S.; Reinhardt, M.; Schnitzer, R.; Riedel, A.; Lücking, C.H. Cardiac uptake of [123I]MIBG separates Parkinson's disease from multiple system atrophy. Neurology 1999, 53, 1020-1025. [CrossRef] [PubMed]

91. Reinhardt, M.J.; Jüngling, F.D.; Krause, T.M.; Braune, S. Scintigraphic differentiation between two forms of primary dysautonomia early after onset of autonomic dysfunction: Value of cardiac and pulmonary iodine-123 MIBG uptake. Eur. J. Nucl. Med. 2000, 27, 595-600. [CrossRef]

92. Kanzaki, N.; Sato, K.; Hayabara, T. Improved cardiac iodine-123 metaiodobenzylguanidine accumulation after drug therapy in a patient with Parkinson's disease. Clin. Nucl. Med. 1997, 22, 697-699. [CrossRef]

93. Yoshita, M.; Hayashi, M.; Hirai, S. Decreased myocardial accumulation of 123I-meta-iodobenzyl guanidine in Parkinson's disease. Nucl. Med. Commun. 1998, 19, 137-142. [CrossRef]

94. Druschky, A.; Hilz, M.J.; Platsch, G.; Radespiel-Tröger, M.; Druschky, K.; Kuwert, T.; Neundörfer, B. Differentiation of Parkinson's disease and multiple system atrophy in early disease stages by means of I-123-MIBG-SPECT. J. Neurol. Sci. 2000, 175, 3-12. [CrossRef]

95. Satoh, A.; Serita, T.; Seto, M.; Tomita, I.; Satoh, H.; Iwanaga, K.; Takashima, H.; Tsujihata, M. Loss of 123I-MIBG uptake by the heart in Parkinson's disease: Assessment of cardiac sympathetic denervation and diagnostic value. J. Nucl. Med. 1999, 40, 371-375.

96. Serita, T.; Satoh, A.; Tanigawa, M.; Seto, M.; Seto, S.; Tsujihata, M.; Yano, K. Total Defect of Metaiodobenzylguanidine (MIBG) Imaging on Heart in Parkinson's Disease (PD). J. Nuclear Cardiol. 1997, 1, S101. [CrossRef]

97. Orimo, S.; Takahashi, A.; Uchihara, T.; Mori, F.; Kakita, A.; Wakabayashi, K.; Takahashi, H. Degeneration of cardiac sympathetic nerve begins in the early disease process of Parkinson's disease. Brain Pathol. 2007, 17, 24-30. [CrossRef]

98. Goldstein, D.S. Orthostatic hypotension as an early finding in Parkinson's disease. Clin. Auton. Res. 2006, 16, 46-54. [CrossRef]

99. Goldstein, D.S.; Sharabi, Y.; Karp, B.I.; Bentho, O.; Saleem, A.; Pacak, K.; Eisenhofer, G. Cardiac sympathetic denervation preceding motor signs in Parkinson disease. Clin. Auton. Res. 2007, 17, 118-121. [CrossRef] [PubMed]

100. Jain, S.; Goldstein, D.S. Cardiovascular dysautonomia in Parkinson disease: From pathophysiology to pathogenesis. Neurobiol. Dis. 2012, 46, 572-580. [CrossRef] [PubMed]

101. Bryant, M.S.; Jackson, G.R.; Hou, J.G.; Protas, E.J. Treadmill exercise tests in persons with Parkinson's disease: Responses and disease severity. Aging Clin. Exp. Res. 2016, 28, 1009-1014. [CrossRef]

102. Gai, W.P.; Geffen, L.B.; Denoroy, L.; Blessing, W.W. Loss of C1 and C3 epinephrine-synthesizing neurons in the medulla oblongata in Parkinson's disease. Ann. Neurol. 1993, 33, 357-367. [CrossRef]

103. Forno, L.S.; Alvord, E.C. Depigmentation in the nerve cells of the substantia nigra and locus ceruleus in Parkinsonism. Adv. Neurol. 1974, 5, 195-202. [PubMed]

104. Kish, S.J.; Shannak, K.S.; Rajput, A.H.; Gilbert, J.J.; Hornykiewicz, O. Cerebellar norepinephrine in patients with Parkinson's disease and control subjects. Arch. Neurol. 1984, 41, 612-614. [CrossRef] [PubMed] 
105. Zweig, R.M.; Cardillo, J.E.; Cohen, M.; Giere, S.; Hedreen, J.C. The locus ceruleus and dementia in Parkinson's disease. Neurology 1993, 43, 986-991. [CrossRef] [PubMed]

106. Jellinger, K.A. Pathology of Parkinson's disease. Changes other than the nigrostriatal pathway. Mol. Chem. Neuropathol. 1991, 14, 153-197. [CrossRef]

107. Wakabayashi, K.; Toyoshima, Y.; Awamori, K.; Anezaki, T.; Yoshimoto, M.; Tsuji, S.; Takahashi, H. Restricted occurrence of Lewy bodies in the dorsal vagal nucleus in a patient with late-onset parkinsonism. J. Neurol. Sci. 1999, 165, 188-191. [CrossRef]

108. Halliday, G.M.; Li, Y.W.; Blumbergs, P.C.; Joh, T.H.; Cotton, R.G.; Howe, P.R.; Blessing, W.W.; Geffen, L.B. Neuropathology of immunohistochemically identified brainstem neurons in Parkinson's disease. Ann. Neurol. 1990, 27, 373-385. [CrossRef] [PubMed]

109. Goldstein, D.S. Dysautonomia in Parkinson's disease: Neurocardiological abnormalities. Compr. Physiol. 2014, 4, 805-826. [CrossRef]

110. Wakabayashi, K.; Takahashi, H. Neuropathology of autonomic nervous system in Parkinson's disease. Eur. Neurol. 1997, 38 (Suppl. 2), 2-7. [CrossRef]

111. Low, D.A.; Vichayanrat, E.; Iodice, V.; Mathias, C.J. Exercise hemodynamics in Parkinson's disease and autonomic dysfunction. Parkinsonism Relat. Disord. 2014, 20, 549-553. [CrossRef]

112. Sabino-Carvalho, J.L.; Teixeira, A.L.; Samora, M.; Daher, M.; Vianna, L.C. Blunted cardiovascular responses to exercise in Parkinson's disease patients: Role of the muscle metaboreflex. J. Neurophysiol. 2018, 120, 1516-1524. [CrossRef]

113. Sabino-Carvalho, J.L.; Vianna, L.C. Altered cardiorespiratory regulation during exercise in patients with Parkinson's disease: A challenging non-motor feature. SAGE Open Med. 2020, 8, 2050312120921603. [CrossRef]

114. Ludin, S.M.; Steiger, U.H.; Ludin, H.P. Autonomic disturbances and cardiovascular reflexes in idiopathic Parkinson's disease. J. Neurol. 1987, 235, 10-15. [CrossRef]

115. Krämer, H.H.; Lautenschläger, G.; de Azevedo, M.; Doppler, K.; Schänzer, A.; Best, C.; Oertel, W.H.; Reuter, I.; Sommer, C.; Birklein, F. Reduced central sympathetic activity in Parkinson's disease. Brain Behav. 2019, 9, e01463. [CrossRef]

116. Shindo, K. Age and duration related changes in muscle sympathetic nerve activity in Parkinson's disease. J. Neurol. Neurosurg. Psychiatry 2003, 74, 1407-1411. [CrossRef] [PubMed]

117. Sharabi, Y.; Imrich, R.; Holmes, C.; Pechnik, S.; Goldstein, D.S. Generalized and neurotransmitter-selective noradrenergic denervation in Parkinson's disease with orthostatic hypotension. Mov. Disord. 2008, 23, 1725-1732. [CrossRef] [PubMed]

118. Senard, J.M.; Rascol, O.; Durrieu, G.; Tran, M.A.; Berlan, M.; Rascol, A.; Montastruc, J.L. Effects of yohimbine on plasma catecholamine levels in orthostatic hypotension related to parkinson disease or multiple system atrophy. Clin. Neuropharmacol. 1993, 16, 70-76. [CrossRef]

119. Joyner, M.J.; Casey, D.P. Regulation of increased blood flow (hyperemia) to muscles during exercise: A hierarchy of competing physiological needs. Physiol. Rev. 2015, 95, 549-601. [CrossRef] [PubMed]

120. Thomas, G.D.; Segal, S.S. Neural control of muscle blood flow during exercise. J. Appl. Physiol. 2004, 97, 731-738. [CrossRef]

121. Behnke, B.J.; Padilla, D.J.; Ferreira, L.F.; Delp, M.D.; Musch, T.I.; Poole, D.C. Effects of arterial hypotension on microvascular oxygen exchange in contracting skeletal muscle. J. Appl. Physiol. 2006, 100, 1019-1026. [CrossRef]

122. Wright, J.R.; McCloskey, D.I.; Fitzpatrick, R.C. Effects of muscle perfusion pressure on fatigue and systemic arterial pressure in human subjects. J. Appl. Physiol. 1999, 86, 845-851. [CrossRef]

123. Wright, J.R.; McCloskey, D.I.; Fitzpatrick, R.C. Effects of systemic arterial blood pressure on the contractile force of a human hand muscle. J. Appl. Physiol. 2000, 88, 1390-1396. [CrossRef]

124. Fitzpatrick, R.; Taylor, J.L.; McCloskey, D.I. Effects of arterial perfusion pressure on force production in working human hand muscles. J. Physiol. 1996, 495, 885-891. [CrossRef]

125. Ahlqvist, G.; Landin, S.; Wroblewski, R. Ultrastructure of skeletal muscle in patients with Parkinson's disease and upper motor lesions. Lab. Invest. 1975, 32, 673-679. [PubMed]

126. Bindoff, L.A.; Birch-Machin, M.A.; Cartlidge, N.E.; Parker, W.D.; Turnbull, D.M. Respiratory chain abnormalities in skeletal muscle from patients with Parkinson's disease. J. Neurol. Sci. 1991, 104, $203-208$. [CrossRef] 
127. Shoffner, J.M.; Watts, R.L.; Juncos, J.L.; Torroni, A.; Wallace, D.C. Mitochondrial oxidative phosphorylation defects in parkinson's disease. Ann. Neurol. 1991, 30, 332-339. [CrossRef] [PubMed]

128. Nakagawa-Hattori, Y.; Yoshino, H.; Kondo, T.; Mizuno, Y.; Horai, S. Is Parkinson's disease a mitochondrial disorder? J. Neurol. Sci. 1992, 107, 29-33. [CrossRef]

129. Cardellach, F.; Martí, M.J.; Fernández-Solá, J.; Marín, C.; Hoek, J.B.; Tolosa, E.; Urbano-Márquez, A. Mitochondrial respiratory chain activity in skeletal muscle from patients with Parkinson's disease. Neurology 1993, 43, 2258-2262. [CrossRef]

130. Blin, O.; Desnuelle, C.; Rascol, O.; Borg, M.; Peyro Saint Paul, H.; Azulay, J.P.; Billé, F.; Figarella, D.; Coulom, F.; Pellissier, J.F. Mitochondrial respiratory failure in skeletal muscle from patients with Parkinson's disease and multiple system atrophy. J. Neurol. Sci. 1994, 125, 95-101. [CrossRef]

131. Wiedemann, F.R.; Winkler, K.; Lins, H.; Wallesch, C.W.; Kunz, W.S. Detection of respiratory chain defects in cultivated skin fibroblasts and skeletal muscle of patients with Parkinson's disease. Ann. N. Y. Acad. Sci. 1999, 893, 426-429. [CrossRef]

132. Anderson, J.J.; Bravi, D.; Ferrari, R.; Davis, T.L.; Baronti, F.; Chase, T.N.; Dagani, F. No evidence for altered muscle mitochondrial function in Parkinson's disease. J. Neurol. Neurosurg. Psychiatry 1993, 56, 477-480. [CrossRef]

133. DiDonato, S.; Zeviani, M.; Giovannini, P.; Savarese, N.; Rimoldi, M.; Mariotti, C.; Girotti, F.; Caraceni, T. Respiratory chain and mitochondrial DNA in muscle and brain in Parkinson's disease patients. Neurology 1993, 43, 2262-2268. [CrossRef]

134. Reichmann, H.; Janetzky, B.; Bischof, F.; Seibel, P.; Schöls, L.; Kuhn, W.; Przuntek, H. Unaltered respiratory chain enzyme activity and mitochondrial dna in skeletal muscle from patients with idiopathic parkinson's syndrome. ENE 1994, 34, 263-267. [CrossRef]

135. Taylor, D.J.; Krige, D.; Barnes, P.R.J.; Kemp, G.J.; Carroll, M.T.; Mann, V.M.; Cooper, J.M.; Marsden, C.D.; Schapira, A.H.V. A 31P magnetic resonance spectroscopy study of mitochondrial function in skeletal muscle of patients with Parkinson's disease. J. Neurol. Sci. 1994, 125, 77-81. [CrossRef]

136. Mann, V.M.; Cooper, J.M.; Krige, D.; Daniel, S.E.; Schapira, A.H.; Marsden, C.D. Brain, skeletal muscle and platelet homogenate mitochondrial function in Parkinson's disease. Brain 1992, 115, 333-342. [CrossRef]

137. Winkler-Stuck, K.; Kirches, E.; Mawrin, C.; Dietzmann, K.; Lins, H.; Wallesch, C.-W.; Kunz, W.S.; Wiedemann, F.R. Re-evaluation of the dysfunction of mitochondrial respiratory chain in skeletal muscle of patients with Parkinson's disease. J. Neural. Transm. 2005, 112, 499-518. [CrossRef] [PubMed]

138. Ercan, A.; Kulaksiz, G.; Dalmizrak, O.; Muftuoglu, M.; Ogus, İ; Cavdar, L.; İnan, L.; Nazmi, O. Mitochondrial Respiratory Chain Enzyme Activities, mtDNA Variants and Gene Expression Levels in Idiopathic Parkinson's Disease. Turk. J. Biochem. 2009, 34, 97-104.

139. Gdynia, H.-J.; Sperfeld, A.-D.; Unrath, A.; Ludolph, A.C.; Sabolek, M.; Storch, A.; Kassubek, J. Histopathological analysis of skeletal muscle in patients with Parkinson's disease and “dropped head'/'bent spine" syndrome. Parkinsonism Relat. Disord. 2009, 15, 633-639. [CrossRef] [PubMed]

140. Afshari, M.; Yang, A.; Bega, D. Motivators and barriers to exercise in Parkinson's disease. J. Parkinson's Dis. 2017, 7, 703-711. [CrossRef]

141. Flach, A.; Jaegers, L.; Krieger, M.; Bixler, E.; Kelly, P.; Weiss, E.P.; Ahmad, S.O. Endurance exercise improves function in individuals with Parkinson's disease: A meta-analysis. Neurosci. Lett. 2017, 659, 115-119. [CrossRef]

142. Armstrong, M.J.; Okun, M.S. Diagnosis and treatment of Parkinson disease: A Review. JAMA 2020, $323,548$. [CrossRef]

143. Aburub, A.; Ledger, S.J.; Sim, J.; Hunter, S.M. Cardiopulmonary Function and Aerobic Exercise in Parkinson's: A systematic review of the literature. Mov. Disord. Clin. Pract. 2020, 7, 599-606. [CrossRef]

Publisher's Note: MDPI stays neutral with regard to jurisdictional claims in published maps and institutional affiliations. 